\title{
How Should the Law Treat Couples Who Live Apart Together?
}

\author{
Cynthia Grant Bowman*
}

Committed couples who do not share a residence, commonly called 'LATs' (for Living Apart Together), have been little studied by family law scholars in the United States. After describing the literature on this phenomenon by British, European, Canadian, and Australian scholars, this article provides new data about LATs in the US. It presents the results of two new surveys, one of respondents in New York State and one US-wide study, along with information gleaned from qualitative interviews of LATs. These data show that LATs are as prevalent in the US as elsewhere and provide information about their lifestyle, their reasons for living apart, their economic relationships, and the family-like functions LATs undertake for each another. The article then discusses whether the US legal system should recognize LAT relationships and, if so, for what purposes, concluding that certain legal rights should be extended to LATs, limiting them in most instances to those designed to aid their mutual caretaking, not those premised on economic interdependence.

\section{Introduction}

Among the new forms of adult affiliation increasingly competing with marriage is 'living apart together,' or LAT, as it has become known. LATs are committed unmarried couples who maintain separate residences. New modes of intimate relationship, such as cohabitation and LAT, respond to changed social and economic circumstances, in which women are seeking equality with men in both the workplace and the home yet the economy demands full time dedication from workers. Our family law, by contrast, has traditionally been premised on a nuclear family model and fails to address alternative ways of living. While LATs have been extensively studied in other countries, they are virtually unstudied in the United States, largely due to the lack of statistics.

\footnotetext{
* Dorothea S. Clarke Profes s or of Law, Cornell Law School. I am grateful for the financial support of the Dorothea S. Clarke Program in Feminist Juris prudence at Cornell Law School and for suggestions and comments by my colleagues at Cornell Law School; Robert A. Pollak and the participants in the Washington University Department of Economics workshop on Work, Family, and Public Policy; Anne Barlow and the students in her Family Law and Social Change seminar at the University of Exeter School of Law; Simon Duncan; Jo Miles; and participants at the meeting of the Socio-Legal Studies Association in Newcastle-upon-Tyne in April 2017. I also thank Amy Emerson of the Cornell Law Library and my ass is tant Ernestine DaSilva for supplying me with countless materials, and Martin $\mathrm{T}$. Wells for helping me interpret data from the 2016 surveys. I especially appreciate the generosity of the LAT couples in New York City, Ithaca, New York, and England, who consented to be interviewed by me in person.
} 
This article is the first attempt by a family law scholar to explore this phenomenon in the US and to consider how it should be treated by the law.

In reaching conclusions about the appropriate legal treatment of LATs, it is important to know as much as possible about these couples and how they live, including their reasons for doing so, their economic arrangements, and the family-like functions they do or do not perform for each other. Part I, below, reviews findings about LATs in social scientific literature, mostly from the UK. In Part II, I describe and discuss the results of empirical work about LATs conducted during 2016 and 2017, including two surveys by the Cornell Survey Research Institute and information gained in a series of qualitative interviews. Based on these findings, Part III discusses what the legal status of these couples should be, concluding with several specific proposals for legal change.

\section{Literature Review: What Do We Know about LATs from Studies in Other Countries?}

Studies of LATs have been carried out mostly by sociologists and demographers, not by legal scholars. Topics they have explored include (a) numbers and demographic characteristics of couples living apart; (b) the division of LATs into age groups, or life stages, and their varying reasons for living separately; and (c) the economic arrangements and caregiving between LAT partners.

\section{Numbers and Demography}

Scandinavia appears always to be the pioneer in new family forms; certainly that was true of cohabitation. ${ }^{1}$ Early studies of LATs also emerged from that part of Europe. Several large surveys in Sweden during the 1990s reported that $2 \%$ to $4 \%$ of respondents were LATs; another study showed a dramatic increase in the number of LATs, from $6 \%$ of unmarried, non-cohabiting adults in Sweden in 1993, to $12 \%$ in 1998 , and $14 \%$ in $2001 .^{2}$ In Norway, LATs made up $8 \%$ of all those aged from 18 to 74 in $2002 .{ }^{3}$ Studies from the Continent confirmed the prevalence of this

\footnotetext{
${ }^{1}$ C Sörgjerd, Reconstructing Marriage: The Legal Status of Relationships in a Changing Society (Intersentia, 2012), at $\mathrm{p} 16$.

2 I Levin and J Trost, “'Living Apart Together”' 2 Community, Work and Family 279, 281-283 (1999); I Levin, 'Living Apart Together: A New Family Form', 52 Current Sociology 223, 228-229 (2004).

${ }^{3}$ Ibid, p 229.
} 
phenomenon. ${ }^{4}$ Surveys in Australia and Canada reported that $7 \%$ to $9 \%$ of the adult population were LATs, and the one study estimating the numbers in the US reported similar percentages. ${ }^{5}$

The increase in the number of LATs over a relatively brief period of time is notable. Some scholars surmise that a mélange of causes is responsible for this increase. ${ }^{6}$ For example, high divorce rates and low mortality rates mean that the potential population of LATs is large. Increases in gender equality mean that women now both participate in the paid labour market and resist traditional divisions of labour at home. Increased travel, as well as increased globalization of the job market, mean that couples meet and fall in love even though they live and work in different places. And advances in communication, ranging from Internet dating to email, texting, Skype, and other technologies that facilitate contact across distance make this living arrangement more possible than it was in the past. All of these causative factors appear likely to continue, and thus the incidence of LAT is likely to continue to increase.

The largest number of studies of LATs have been carried out in the UK, in part due to the availability of statistics about LATs in the Omnibus Survey, the British Household Panel Survey, and the British Social Attitudes Survey. Based on the 2002 and 2003 Omnibus Survey, John Haskey reported that about 2 million individuals between the ages of 16 and 59 were LAT, excluding students and those living with the household head, which would have doubled the number. ${ }^{7}$ (The British thought the question about this living arrangement too sensitive to ask of

${ }^{4}$ A Régnier-Loilier et al, 'Neither Single, Nor in a Couple: A Study of Living Apart Together in France', 21 Demographic Research 75, 85 (2009) (reporting that 10\% of French men and 11\% of French women between 18 and 79 were LATs); JB Asendorpf, 'Living Apart Together: Alters- und Kohortenabhangigkeit einer heterogenen Lebensform', 4 Kolner Zeitschrift fur Soziologie und Sozialpschologie 749, 761 (2008) (concluding that 29\% of the single population of Germany were LATs).

${ }^{5}$ A Reimondos, A Evans andEGray, 'Living-apart-together (LAT) relationships in Australia', 87 Family Matters 43, 43-44 (2011) (reporting based on nationally representative survey of Australian population aged 18 and older that 7\% to $9 \%$ were LAT, 24\% of the single population); A Milan and A Peters, 'Couples Living Apart', Canadian Social Trends (Summer 2003), p 3 (reporting that about $8 \%$ of the Canadian population over the age of 20 were LAT); CQ Strohmet al, "Living Apart Together" Relationships in the United States', 21 Demographic Research 177, 190-192 (2009) (reporting that 7\% of women and 6\% of men in the US were LATs, but higher percentages (12-13\%) in California, amounting to $35 \%$ of all adults who were not married or cohabiting).

${ }^{6}$ Levin, above note 2, pp 224-25, 237-38; see also J Trost, 'LAT Relationships Now and in the Future', in KMatthijs (ed.), The Family: Contemporary Perspectives and Challenges (Cornell University Press, 1998), at pp 217-219.

${ }^{7}$ J Haskey, 'Living Arrangements in Contemporary Britain: Having a Partner Who Usually Lives Elsewhere and Living Apart Together(LAT)', 122 Population Trends 35, 42 (2005). 
respondents aged 60 and older. ${ }^{8}$ ) On the 2004 Omnibus Survey, 19\% of single men and 21\% of single women said they had a partner with whom they did not live, compared to $23 \%$ of men and $27 \%$ of women cohabiting. ${ }^{9}$ These surveys led Simon Duncan and Miranda Phillips, who have published (with a variety of co-authors) numerous articles exploring the LAT phenomenon, to conclude that $10 \%$ of adults in Great Britain are LATs, more than $25 \%$ of all those not married or cohabiting; thus identifying them as single is inaccurate $25 \%$ of the time. ${ }^{10}$

Studies that have inquired about the length of LAT relationships report that duration has a significant correlation to the age of the partners. Surveys that include the youngest group, aged 18 and up, tend to show that LAT relationships are of relatively short duration, even considering the fact that their young age makes long length of relationships unlikely. One large-scale study in Australia of all adults 18 and over, for example, reported a mean duration of 2.4 years and a median of 1.5 years. ${ }^{11}$ However, $28 \%$ of the LATs in that same study stayed together as a couple for three years or longer, including almost half of those aged 45 and over. ${ }^{12}$ A smaller, qualitative study of LATs in Belgium reported an average duration of 5.7 years. ${ }^{13}$

However, studies focused on LATs who were 55 and older showed partnerships of much longer duration: $46 \%$ of French LATs aged 55 and older had been together with their partners for more than nine years; ${ }^{14}$ the average duration for Swedes aged 60 and older was seven years; ${ }^{15}$ and

\footnotetext{
${ }^{8} \mathrm{~J}$ Haskey and J Lewis, 'Living-apart-together in Britain: Context and Meaning', 2 International Journal of Law in Context 37, 39 (2006).

${ }^{9}$ Ibid.

${ }^{10}$ S Duncan and M Phillips, 'People Who Live Apart Together (LATs): New Family Form or Just a Stage?' 21 International Review of Sociology 513, 515 (2011).

${ }^{11}$ Reimondos et al., above note 5, p 48.

${ }^{12}$ Ibid.

${ }^{13}$ V Lys sens-Danneboom and D Mortelmans, 'Living Apart Together and Money: New Partnerships, Traditional Gender Roles', 76 Journal of Marriage and Family 949, 953 (2014) (the 54 participants, thou gh drawn froma sample aged 18 and over, tended to be older).

${ }^{14}$ Régnier-Loilier et al, above note 4, p 97.

${ }^{15}$ SG Karls s on et al, 'Caring While Living Apart', 49 Journalof Gerontological Social Work 3, 16 (2007).
} 
the average duration for Canadian LATs between the ages of 39 and 92 was 10 years. ${ }^{16}$ This variance in duration between younger and older LATs makes sense in light of the fact that, for the youngest group, coupledom of any sort is new and living apart may simply be a transitional phenomenon, while for the age group in the middle, it is often a choice that is constrained by external factors. One study of LATs of all ages in Germany suggested that the overall four-year duration was a result of ' 45 per cent dissolving, 35 per cent being converted into a cohabiting union and 10 per cent converting into a marriage within 10 years' (with 10 per cent presumably continuing). ${ }^{17}$ Thus the four-year average included within it both unions that were quite brief and others that were transformed into cohabitation or marriage after a fairly long period of time.

The few studies that discuss the income groups into which LATs fall suggest that they are comfortably well off economically. ${ }^{18}$ Certain assumptions may be drawn about LATs simply from their living arrangements. By definition, each has his or her own residence. If, as Haskey suggests, we exclude younger persons who are still living with their families of origin and/or still dependent on them, LATs are also by definition self-sufficient economically. A certain income level is necessary to support these two conditions. ${ }^{19}$

The similarly few studies about the educational level of LATs have suggested that they are well educated. One small-scale Canadian study reported that $41 \%$ of those interviewed had a university or postgraduate degree. ${ }^{20}$ The one study heretofore of LATs in the United States found that they were almost twice as likely as cohabitants to have a college degree (33\% for women LATs and $18 \%$ for women cohabitants; $29 \%$ for male LATs and $16 \%$ for male cohabitants) and to

\footnotetext{
${ }^{16}$ LM Funk and KM Kobayashi, 'From Motivations to Accounts: An Interpretive Analysis of "Living Apart Together" Relationships in Mid- to Later-Life Couples', 37 Journal of Family Issues 1101, 1106 (2016).

${ }^{17}$ J Ermisch and T Siedler, 'Living Apart Together', in M Brynin and J Ermisch (eds), Changing Relationships (Routledge, 2009), at p 30.

${ }^{18}$ Funk and Kobay ashi, above note 16,pp 1105-1106 (reporting that $82 \%$ of LATs over the age of 25 who identified their choice to live apart as based on preference and had been together at least three years made in excess of $\$ 40,000$ per year). Contrast Milan and Peters, above note 5, p 4 (reporting that 74\% of LATs, including those who were very young, had incomes below $\$ 40,000)$.

${ }^{19}$ K Upton-Davis, 'Living Apart Together Relationships (LAT): Severing Intimacy from Obligation', 29 Gender Issues 25, 34 (2012).

${ }^{20} \mathrm{Ibid}$.
} 
be college graduates at about the same rate as married persons. ${ }^{21}$ In contrast, a study of LATs in Scotland reported that not all of those interviewed were highly educated and economically advantaged. ${ }^{22}$

Although there are some studies of long-distance LATs, ${ }^{23}$ the majority appear to live close to one another. Turcotte reported that $34 \%$ of LATs in Canada lived within a 30 to 60 minute drive of one another, and $45 \%$ in the same neighborhood. ${ }^{24}$ In the UK, according to Duncan et al., $18 \%$ of LATs live within one mile of one another; $29 \%$ live from one to five miles apart, $17 \%$ five to 10 miles, $19 \% 10$ to 50 miles apart, and $9 \%$ over 50 miles but both still within the UK (leaving about $8 \%$ outside those boundaries). ${ }^{25}$ In the majority of these situations, therefore, the decision to live apart was not determined by the partners' having jobs or universities in different localities, and more likely to be a matter of choice. Couples who live separately meet very often, with many seeing each other every day or several times a week, and have repeated and frequent contact by telephone, text, or email in between. ${ }^{26}$

\section{Age Groups and Reasons to Live Apart}

The meaning of living apart can differ according to the life stage of the partners; scholars have therefore focused a good deal of attention on the age distribution of LATs. In this section, I discuss the three groups into which LATs may be divided: (1) those who are young and essentially

\footnotetext{
${ }^{21}$ Strohmet al., above note 5, p 191.

${ }^{22}$ L Jamies on and R Simpson, Living Alone: Globalization, Identity and Belonging (Palgrave Macmillan, 2013), at $\mathrm{p}$ 79.
}

${ }^{23}$ D Reuschke, 'Living Apart Together over Long Distances - Time-Space Patterns and Consequences of a LateModern Living Arrangement', 64 Erdkunde 215 (2010). Some couples living in Europe - migrant workers, for example - may live apart across national borders on a semi-permanent basis as a result of economic pressures. C Beauchemin et al, 'Reunifying Vers us Living Apart Together across Borders: A Comparative Analysis of Sub-Saharan Migration to Europe', 49 International Migration Review 173 (2015). Couples separated by military service or imprisonment also would fall in to this group.

${ }^{24}$ M Turcotte, 'Living Apart Together', Statistics Canada (March 2013), p 3.

${ }^{25}$ S Duncan et al., 'Practices and Perceptions of Living Apart Together', 5 Family Science 1, 2 (Table 1) (2014). See also Ermisch and Siedler, above note 17, p 41 (reporting that in both Germany and the UK 60\% to 65\% of LATs live within five miles of one another).

${ }^{26}$ Duncan et al., above note $25, \mathrm{p} 3$ (reporting that $44 \%$ of LATs living within one mile of one another saw each other daily and that $85 \%$ to $90 \%$ of all LATs had contact by phone, text, or email a least once a day and $55 \%$ multiple times a day); SGKarlss on and K Borell, 'Intimacy and Autonomy, Gender and Ageing: Living Apart Together', 27 Ageing International 11, 15 (2002) (reporting that 36\% of Swedish LATs aged 60 and over had daily contact, $51 \%$ several times a week, and only $12 \%$ twice a month or less). 
'dating'; (2) those who are in the period when people traditionally marry, build their careers, and raise children; and (3) those who are past that stage of life. Dividing LATs into these three groups goes a long way toward understanding why people choose to couple but not share a residence and how those reasons differ by age group, as well as the relationship between the duration of LAT relationships and the age of the partners.

\section{Young LATS}

Haskey has said that about half of LATs in the UK are under 25, which is consistent with reports from other countries. ${ }^{27}$ However the statistics are reported, it is clear that living apart is an important arrangement for couples who are young. It is not difficult to see why this is so. LATs who are under 24 are likely still to be students, perhaps living at home, especially in European countries where both economics and customs keep unmarried adults in their parental home; and most of them are not yet financially independent. ${ }^{28}$ These conditions prevent them from cohabiting. They may also still be testing the relationship. ${ }^{29}$ Whether due to constraints imposed by family, work, or education or because of uncertainty about the particular partner, the LAT relationship among this age group is likely to be temporary or transitional. ${ }^{30}$ One may refer to this group, as Duncan and Phillips do, as 'dating LATs.' 31

\section{LATs in midlife}

The 'middle' group of LATs consists of adults somewhere in the range of 25 or 30 to 55 years old, the years of child-rearing and career-building. Many of the LATs among them have been previously married or have lived with a partner, and many have children from those

\footnotetext{
${ }^{27}$ Haskey, abovenote 7, p 39; Reimondos et al, above note 5, p 49 (Table 1) (44\% of LATs in Australia were between 18 and 24); Milan and Peters, above note 5, p 3 (54\% of male and 57\% of female LATs in Canada were between 20 and 29); Régnier-Loiler et al., above note 4. p 87 (Table 3) (65\% of men and 54\% of women in France between 18 and 24 who were partnered were LAT).

${ }^{28}$ Ibid, p 85. T Castro-Martin, M Dominguez-Folgueras and T Martin-Garcia, 'Not Truly Partnerless: Non-residential Partnerships and Retreat from Marriage in Spain', 18 Demographic Research 443, 448-449 (2008) (describing residential patterns of young adults in Spain, where custom, as well as current economic conditions, high unemployment, and lack of affordable housing contribute to late departure from the natal family).

${ }^{29}$ C Villeneuve-Gokalp, 'Vivre en Couple Chacun ChezSoi', 52 Population 1059, 1062 (1997).

${ }^{30} \mathrm{Ibid}, \mathrm{p} 1063$ (reporting that only 12\% of French LATs in this age group stayed together for five years).

${ }^{31}$ Duncan and Phillips, above note 10, p 529.
} 
relationships. ${ }^{32}$ Their reasons for living in a separate residence from a romantic partner run the gamut from the voluntary to the involuntary with varying degrees of volition and constraint in between. Some, for example, have jobs in different locations that prevent their living in the same place. ${ }^{33}$ Others have obligations to children and desire to avoid the difficulties associated with blended families. ${ }^{34}$ Their children may not like the partner and be adamant about not moving away from the family home, school, and neighborhood. ${ }^{35}$ Some LATs may be caring for elderly relatives either in their home or under circumstances that make moving in with a partner impossible or undesirable. ${ }^{36}$ Living apart for this group of reasons may be temporary; when the constraint is removed - a job found in the same place, children grown up or parents deceased, a mutually suitable residence found - the couple is free to cohabit.

Another category of reasons given for living apart is economic and less tractable. Although it seems a truism that one home is cheaper than two, it can in fact be very expensive to buy a new house that is large enough for two families. ${ }^{37}$ New York City, for example, with its extremely expensive housing, can present many obstacles to moving in together - for example, if one or the other partner has a lease on an apartment on which the rent is controlled below its market price or owns a property bought so long ago that the capital gains tax that would arise upon sale would be prohibitive and a comparable home not affordable. ${ }^{38}$ Moreover, if one partner gives up his or her home to move in with the other, the security of that investment and the knowledge that one always

\footnotetext{
${ }^{32}$ Funk and Kobayashi, above note 16, pp 1106-1107; Régnier-Loilieret al, above note4, p 86.

${ }^{33}$ Ibid, p 105; Duncan et al, 'Why Do People Live Apart Together?' 2 Families, Relationships and Societies 323, 328-329 (2013); Levin, above note 2, pp 232-33; Levin and Trost, above note 2, pp 285-286.

${ }^{34}$ Lys s ens-Danneboomand Mortelmans, above note 13, p 956; Villeneuve-Gokalp, above note 29, p 1072; Levin and Trost, above note 2, pp 283-84.

${ }^{35}$ Levin, above note 2, p 230; Funk and Kobayashi, above note 16, p 1113.

${ }^{36}$ Levin, above note 2, p 231.

${ }^{37}$ Régnier-Loilier et al, above note 4, p 105; Funk and Kobayashi, above note 16, p 1112.

${ }^{38}$ C Rosenblum, 'Together With an *', N.Y. Times, 15 Sept 2013, sec. RE, p 1 (describing some of the unique real es tate problems faced by LATs who live in New York City). This would not happen in the UK, where one's principal private residence is exempt from capital gains tax.
} 
has a place to live disappears. ${ }^{39}$ In some situations, in some countries, including the UK, moving in with a partner may also lead to a reduction in social security, pension payments, or welfare benefits. ${ }^{40}$ In the United States, it can also result, depending on a state's law, in the automatic termination of spousal support payments from a partner's ex-spouse. ${ }^{41}$

LATs in this middle group also report reasons for living apart that are more voluntary than constrained. They are attached to their own homes. ${ }^{42}$ Their styles clash with their partner's - in home décor, tidiness or cleanliness, hobbies, habits of sleeping and waking, and the like. ${ }^{43}$ They want to maintain their own friends and way of life without feeling any sense of constraint, at least during some part of the week. ${ }^{44}$ They need both time and space for their own interests. ${ }^{45}$ Women in particular are concerned about loss of their identity and want to avoid risks, both economic and emotional, which they have encountered in past relationships. ${ }^{46}$ This may include both a gendered division of labour or a tendency to defer to the partner's choices, on the one hand, and the economic devastation experienced upon divorce, on the other. ${ }^{47}$ For all these reasons, autonomy and independence have become centrally important to these women. ${ }^{48}$ Finally, some LATs fear that

\footnotetext{
${ }^{39}$ S Roseneil, 'On Not Living with a Partner: Unpicking Coupledomand Cohabitation', 11(3) Sociological Research Online 10(2006).

${ }^{40}$ Lys sens-Danneboomand Mortelmans, above note 13, p 956; Duncan et al., above note 33, p 328 (Table 2).

${ }^{41}$ See below, text accompanying note 118. This might als o happen in England and Wales, but would depend on the wording of the original order or result from an application to the court for discretionary termination in light of the payee's new relationship (cfthe automatic termination that arises on remarriage under Matrimonial Causes Act 1973, s 28(1)(a)).

${ }^{42}$ S Duncan and M Phillips, 'People Who Live Apart Together(LATs) - How Different Are They?' 58 Sociological Review 112, 120 (Table 2) (2010); Funk and Kobayashi, above note 16, p 1109.

${ }^{43}$ Ibid. This consideration was rais ed numerous times by LATs interviewed by the author as well.

${ }^{44}$ Levin and Trost, above note 2, p 286; Has key and Lewis, above note 8, p 45.

${ }^{45}$ Roseneil, above note 39,p 8; Funk and Kobayashi, abovenote 16, pp 1108-1109.

${ }^{46}$ Levin and Trost, above note 2, pp 286-287; Funk and Kobayashi, above note 16, p 1112.

${ }^{47}$ Ibid, p 1115; Duncan et al., above note 25, p 4; see also O Or, 'Midlife Women in Second Partnerships Choosing Living Apart Together: An Is raeli Case Study', 28 Israel Studies Review 41, 47 (2013) (describing the effects of previous experiences of 'traumatic economic catastrophe' upon divorce).

${ }^{48}$ Milan and Peters, above note 5, p 4 (34\% of LATs in Canada say they live that way in order to retain their independence); Lys sens-Danneboom, above note 13, p 960 (describing how important independence is to female
} 
stressing the current relationship with the daily struggles inevitable upon living with another person will destroy it. ${ }^{49}$ Thus living apart is a protective measure, intended to value and preserve an intimate relationship.

In other words, many of the persons in the midlife category could live together, but prefer not to. Duncan et al. estimate the percentage of LATs whom they call 'preference LATs' to be $22 \% .{ }^{50}$ Another study, of some 60 LATs between the ages of 25 and 44 in Scotland, reported that this was the chosen and preferred option for about one in six of them, none of whom were under 30 and most of whom - including all of the women - were in their 40s. ${ }^{51}$ These LATs had longterm socially recognised relationships and did not expect or wish ever to live together; they also had no wish for children in the future. ${ }^{52}$

\section{Older LATS}

One study in the Netherlands found that of all those between the ages of 55 and 89 who had repartnered after death or divorce of a former partner, $32 \%$ were LAT (versus $24 \%$ cohabiting and $40 \%$ remarried), with women more likely to make this choice than men. ${ }^{53}$ This group of LATs, who are past the age of child raising and who are retired or approaching retirement, has attracted particular attention from scholars because their choice of the lifestyle appears genuinely voluntary, not constrained by external factors, and because it has implications for caretaking of the elderly.

The reasons older couples give for living apart are quite different from those described by younger LATs. For many, their own home represents a connection to the past and a long-term

LATs in their management of money); Haskey and Lewis, above note 8, p 43 (emphasizing the importance of independence to LATs in the UK).

${ }^{49}$ Roseneil, above note 39, p 8; Funk and Kobayashi, abovenote 16, pp 1111-1112.

${ }^{50}$ Duncan et al., above note 70, p 329.

${ }^{51}$ Jamieson and Simpson, above note 22, pp 78-79.

${ }^{52}$ Ibid.

${ }^{53} \mathrm{~J}$ Gierveld, 'The Dilemma of Repartnering: Considerations of Older Men and Women Entering New Intimate Relationships in LaterLife', 27 Ageing International 61, 65 (2002). See also Turcotte, above note 24, p 4 (Table 2) (in Canada about $2 \%$ of all pers ons 60 and older in 2011 were LATs, up from 2.3\% in 2001); J Gierveld, 'Intra-couple Caregiving of Older Adults Living Apart Together: Commitment and Independence', 34 Canadian Journal on Aging 356, 357 (2015) (5.1\% of those aged 60 to 70 were LATs); Duncan and Phillips, above note 42, p 122 (Table 3) (6\% of all persons aged 55 to 64 , and $5 \%$ of all aged 65 to 97 , in the UK were LATs). 
investment in a particular neighborhood, neither of which they want to lose. ${ }^{54}$ It may also be the place where children and grandchildren come to visit and thus important to relationships with them, as well as being an asset they want to preserve for the younger generation. ${ }^{55}$ An older person's home also embodies financial security, indeed, it is their largest asset, and many people do not want to give it up for reasons that are both economic and emotional. ${ }^{56}$ Or they simply don't want to move and have to fit into someone else's tastes and décor. ${ }^{57}$ If the alternative is remarriage, they would also risk losing pension rights and other benefits in some countries. ${ }^{58}$

In addition, many older people see maintenance of their own residence as an important aspect of autonomy and independence. ${ }^{59}$ Women express this reason in particular, arguing that home is a 'room of one's own', where a woman can be her authentic self rather than losing herself in coupledom. ${ }^{60}$ Women are also eager to avoid an asymmetrical distribution of household labour and unequal demands for caregiving, which they have either experienced in prior unions or assume on the part of men. ${ }^{61}$ Living apart also preserves the autonomy and equality they have gained, perhaps painfully after the termination of previous relationships, and are reluctant to sacrifice, even though they are still eager for intimate connection. Finally, like those in midlife, some older LATs

\footnotetext{
54 '[L]a mais on est le lieu des sou venirs' [home is the place of memories], according to one French scholar. VCaradec, 'Les Formes de la Vie Conjugale des Jeunes Couples “Ầgés”', 51 Population 897, 905, 906 (1996).

${ }^{55}$ Reimondos et al., above note 5, p 53; Gierveld, 'The Dilemma of Repartnering ', above note53,pp 73-74; Caradec, above note 54, p 906.

${ }^{56}$ Ibid, p 906.

${ }^{57}$ JJ Benson and M Coleman, 'Older Adults Developing a Preference for Living Apart Together', 78 Journal of Marriage and Family 797, 804 (2016).

${ }^{58}$ Caradec, above note 54, p 911; Gierveld, 'The Dilemma of Repartnering', above note 53, p 72 (only private pensions may be lost in the Netherlands upon remarriage, not the state pension to which everyone is entitled).

${ }^{59}$ Ibid, pp 71-72 (Netherlands); Caradec, above note 54, at 907 (France); Funk and Kobayashi, above note 16, pp 1107-1110 (Canada).

${ }^{60}$ SG Karls son and K Borell, 'A Home of Their Own: Women's Boundary Work in LAT-Relationships', 19 Joumal of Aging Studies 73, 74-75 (2005). The reference to a 'room of one's own' is to Virginia Woolf's famous essay, A Room of One's Own, published in 1929.

${ }^{61}$ Karlsson and Borell, above note 26,p 24.
} 
believe that living apart is good for their relationship, by allowing them to escape the everyday and preserve the romance. ${ }^{62}$

\section{Economic Arrangements and Caregiving}

With the exception of one study in Sweden and another in Belgium, what we know about the economics of LAT relationships is largely anecdotal. In the words of one Australian LAT, '[W]e keep our money completely separate. I don't know about his financial affairs and he doesn't know about mine - although he's better off financially than I am.' ${ }^{63}$ This seems to be fairly typic al of the way LATs handle their finances, though perhaps with greater and lesser amounts of knowledge about one another's situation. It is distinct from the income-sharing methods of married couples and cohabitants with children, who generally pool resources. ${ }^{64}$ A study of 116 LATs aged 60 and older in Sweden revealed that they kept their finances separate, with each being responsible for his or her own expenses while dividing expenses for joint activities; they had no joint savings or ownership of any type. ${ }^{65}$ Financial autonomy appears to be particularly important to women. One small-scale study of midlife women in second partnerships in Israel revealed how strongly these LATs felt about financial independence - it was 'central to their autonomy'. ${ }^{66}$ These women found it particularly difficult to accept money from a partner, an attitude often forged by previous trauma occasioned by economic disasters upon divorce. ${ }^{67}$ Once able to stand on their own feet again, they were reluctant to give up that independence.

\footnotetext{
${ }^{62}$ Caradec, above note 54, p 907. Journal of Gender Studies 104, 108 (2015). resources).

${ }^{65}$ Karllson and Borell, above note 26,pp 18-19.

${ }^{66}$ Or, above note $47, \mathrm{p} 47$.

${ }^{67}$ Ibid.
}

${ }^{63}$ K Upton-Davis, 'Subverting Gendered Norms of Cohabitation: Living Apart Together for Women over 45', 24

${ }^{64} \mathrm{C}$ Vogler et al, 'Managing Money in New Heterosexual Forms of Intimate Relationships', 37 Journal of SocioEconomics 552, 567 (Table 11) (2008) (married respondents and cohabiting parents use a joint pooling system); KR Heimdal and SK Hous eknecht, 'Cohabiting and Married Couples' Income Organization: Approaches in Sweden and the United States', 65 Journal of Marriage and Family 525, 533 (2003) (a majority of both married and cohabiting couples in the US and Sweden maintain joint finances); C Kenney, 'Cohabiting Couples, Filing Jointly? Resource Pooling and US Poverty Policies', 53 Family Relations 237, 243-246 (2004) (cohabiting parents generally pool 
One study, carried out in Belgium in 2011 and 2012, specifically focused on LATs' handling of money. ${ }^{68}$ This study confirmed that LATs' most common arrangement was to keep their money separate and to divide joint expenses - for food, recreation, vacations and holidays on a 50/50 basis regardless of income disparity between the two partners. ${ }^{69}$ Its authors found that LATs' attitudes toward monetary sharing were starkly gendered: men were more likely to treat money as a collective resource and sharing as an inherent part of being a couple, while women emphasised economic independence and equality. ${ }^{70}$ Women LATs were reluctant to accept money from their partners, not only to avoid problems they had encountered in the past but also 'to avoid an economy of gratitude' leading to a power imbalance based on financial inequality. ${ }^{71}$ In short, the economic arrangements between LATs can carry a lot of freight.

LATs give one another a great deal of support that is not financial, however. Older and long-term LATs in the Netherlands care for their partners when they are in ill health, although they may be ambivalent about accepting such assistance themselves, for fear of losing their independence or being a burden on the other. ${ }^{72}$ Older LATs in Sweden reported receiving more support in these circumstances from their partner than from children and friends. ${ }^{73}$ Asked if they would take care of their partner for some months if he or she were ill, $65 \%$ of the women and $49 \%$ of the men said that they would do so. ${ }^{74}$

By contrast, LATs in the UK responding to a large-scale survey of all age groups appear to count on their families more than their partners for caregiving in illness. ${ }^{75}$ Although some LATs expected practical care from their partners, it was significantly below the level offered in co-

\footnotetext{
${ }^{68}$ Lys s ens-Danneboomand Mortelmans, above note 13, p 955.

${ }^{69}$ Ibid, pp 957-958.

${ }^{70}$ Ibid, p 962.

${ }^{71}$ Ibid, pp 958, 961.

${ }^{72}$ Gierveld, 'Intra-Couple Caregiving', above note 53, pp 361-362.

${ }^{73}$ Karls son et al., above note 102, p 17.

${ }^{74}$ Ibid, p 21 (Table 6).

${ }^{75}$ Duncan et al., above note 15, pp 7-8.
} 
residential partnerships (cohabitation or marriage). ${ }^{76}$ Most (53\%) said that they would expect care from their family of origin instead of from their partner (20\%), although they would turn to their partner for emotional support in the same proportion as they would turn to a family member. ${ }^{77}$ The difference from Sweden may depend on the fact that many younger LATs were included in the UK survey, who are likely still dependent upon and close to their families of origin, whereas LATs in their older years typically have lost their parents and could only turn to their children for help.

Nonetheless, many LATs in the UK reported that they were highly committed to their partners, with some saying that their commitment was as great as if they were married. ${ }^{78}$ More specifically, a desire to avoid commitment was not given as a reason for living apart. ${ }^{79}$ Some scholarly commentators have pointed out that the level of commitment between LATs is remarkable, given that it does not depend on any structural or legal commitment to one another, such as shared housing, children, possessions, or legal obligations attendant upon marriage or, in many countries, upon cohabitation. ${ }^{80}$ LATs' commitment is thus solely voluntary, based on their feelings for the other person.

In the one US study based on qualitative interviews of 25 LATs between the ages of 60 and 88, the respondents expressed reluctance to undertake an obligation to care for their partners in ill health and gave this as a reason to live apart rather than together. ${ }^{81}$ While these older LATs felt highly committed to their partners and expressed a desire to give them both physical and emotional support, they did not want any legal obligation to do so. ${ }^{82}$ This reaction is understandable in light of the functions considered to be private responsibilities in the US. Whereas social welfare programs in Europe have provided universal health care, pensions, and

\footnotetext{
${ }^{76}$ Ibid, p 7.

${ }^{77}$ Ibid (Table 7).

78 J Carter et al., 'Sex, Love and Security: Accounts of Distance and Commitment in Living Apart Together Relations hips', 50 Sociology 576, 582 (2015).

${ }^{79}$ Duncan et al., above note 15, p 24; Haskey and Lewis, above note 8, p 44.

${ }^{80}$ Carter et al., above note 78, pp 589-590.

${ }^{81}$ Benson and Coleman, above note 57, pp 803-804.

${ }^{82}$ Ibid, p 808.
} 
other types of support in old age, in the US these welfare functions are privatised, that is, families must provide their own insurance, savings, and caretaking services. Thus, the authors of the US study thought it not surprising that 'avoidance of obligatory commitments among older LAT partners may be stronger in the United States compared to European countries. 83 Regardless of their desire to avoid legal obligations, however, the US LATs interviewed cared deeply for one another and were 'seeking the same level of intimacy, trust, and companionship that marriage affords.' 84 They clearly were performing many of the functions of a family, although not all of them, and contributing to an improved quality of life in old age. ${ }^{85}$

\section{LATs in the United States: New Empirical Data}

Only two US studies have asked whether respondents had a partner with whom they did not live: the 1996 and 1998 General Social Surveys and the 2004-2005 California Quality of Life Survey. ${ }^{86}$ I set out, therefore, to collect my own dataset. In 2016, I submitted a series of questions about LATs to both the Empire State Poll (ESP), which surveyed respondents in New York State, and the Cornell National Social Survey (CNSS), which surveyed respondents in the continental US $; 87$ both are administered by the Survey Research Institute at Cornell University (SRI) and randomly sample adults aged 18 and over. The CNSS sample is nationally representative, and the ESP results are generalisable to New York State. ${ }^{88}$ I also asked SRI personnel to cross-tabulate the results with various demographic items in the broader survey. Although the sample size in both these surveys is small - 800 respondents to the ESP and 1,000 to the CNSS - they are the only polls specifically eliciting detailed information from people living as LATs in the US to date.

\footnotetext{
${ }^{83}$ Ibid.

${ }^{84}$ Ibid, p 809.

${ }^{85}$ Ibid, pp 809-810.

${ }^{86}$ See Nat'l Opinion Res. Center, General Social Surveys, 1972-2002: Cumulative Codebook Qs. 545-48 (Feb. 2003); UCLA Center for Health Pol'y Res., California Health Interview Survey (2005).
}

${ }^{87}$ Although the addition of Alaska and Hawaii possibly might change the res ults to some unknownextent, the results from this survey will be labeled as 'national' in this study.

${ }^{88}$ Data was collected by telephone, both cellular and land line, the ESP data between 9February 2016 and 19 April 2016, and the CNSS data between 19September 2016 and 13 December 2016. Datas ets from the CNSS are available at https://cisermgmt.cornell.edu/cnss/. 
I also undertook a series of qualitative interviews with LATs in Ithaca, New York and New York City during 2016 and in the UK in early 2017. Interviewees were recruited by word of mouth, that is, by asking colleagues and friends whether they knew any couples who lived in separate residences, the method sociologists refer to as snowballing. I carried out a total of 18 semi-structured interviews of an hour or more in length, 12 with women LATs (four of whom were in two lesbian couples) and six male LATs, one of whom was gay. All were White, with the exception of one Black male. The total included, in almost every case, interviews of both the partners.

I present the results of the New York and national surveys below under the topics discussed in Part I above: (1) the incidence and demography of LAT unions; (2) the age distribution of LATs and their reasons for living apart; and (3) economic relationships and caregiving between the partners. I then describe my findings from the qualitative interviews and present my conclusions, which are at odds with the survey results in some respects, largely as a result of the ages of the interviewees.

\section{Survey Results}

Incidence and demography

Of the 1,000 respondents to the national survey, 93 reported that they were currently in a committed unmarried relationship with someone with whom they did not live. Of the 800 respondents to the NY-based ESP - half of them from upstate New York (more rural and conservative) and half from downstate (the New York metropolitan area) - 103 reported that they were currently in a committed couple relationship with someone with whom they did not live. Ten of the New York LATs responding were in fact married to their LAT partner. ${ }^{89}$ The LAT respondents amounted to about $9 \%$ of the overall respondents to the national survey and $12 \%$ in New York; $9^{90}$ when generalised to the population aged 18 or over, these percentages are comparable

\footnotetext{
${ }^{89}$ The New York survey asked first 'Are you currently in a committed couple relationship with someone with whom you do not live?' and then, as the second question, 'A re you married to that person?' and thus included married pers ons who lived in separate residences with respect to all the questions that followed. As a result, 10 married respondents were included in the New York study. After reviewing the results of the New York survey, Iamended the first question on the nationalsurvey to ask 'A re you currently in a committed but unmarried relationship with someone with whom you do not live?', thus including only unmarried respondents who lived separately in the national data.

${ }^{90}$ When reporting percentages in the text only, Ihave rounded off to the next higher or lower whole number.
} 
to those obtained in the UK and other studies discussed above and higher than those reported by Strohm et al. in the one US study. ${ }^{91}$

The reported duration of the LATs' relationships varied, as set forth in Table $1 .{ }^{92}$

Table 1. Duration of LAT relationships in NY and US

\begin{tabular}{lcc}
\hline Duration & \% of LATs: NY & \% of LATs: US \\
\hline Less than 6 months & 16.7 & 14.0 \\
\hline $\begin{array}{l}6 \text { months to one } \\
\text { year }\end{array}$ & 13.7 & 20.4 \\
\hline $\begin{array}{l}\text { More than one, less } \\
\text { than two years }\end{array}$ & 9.8 & 19.4 \\
\hline Two to five years & 32.4 & 26.9 \\
\hline Five to ten years & 10.8 & 9.7 \\
\hline More than ten years & 16.6 & 9.6 \\
\hline All durations & 100 & 100
\end{tabular}

Defining a couple as 'long-term' if they have been together more than two years, a little under $50 \%$ of the respondents nationally were long-term LATs and $60 \%$ in New York. Regarding shorter relationships as 'dating' (to use Duncan and Phillips' term ${ }^{93}$ ), by contrast, a little over $50 \%$ nationally might be called dating LATs, and around $40 \%$ in New York. The higher percentage of long-term LATs in New York State may indicate that they are LATs by preference rather than constraint. Alternatively, the length of the unions in New York may have been increased by the inclusion of married persons living separately from their spouses.

Similar to those studied in Europe, the majority of LATs in the United States live quite close to one another: $52 \%$ to 5 on both surveys lived less than 10 miles apart, and $76 \%$ within 50 miles of one another.

\footnotetext{
${ }^{91}$ Strohmet al., above note 5.

${ }^{92}$ Unless otherwise specified, the question was answered by all res pondents.

${ }^{93}$ Duncan and Phillips, above note 10, p 529.
} 
Table 2. Distance between LATs in NY and US

\begin{tabular}{l|c|c}
\hline Distance & \% of LATs: NY & \% of LATs: US \\
\hline 1 mile or less & 17.5 & 17.2 \\
\hline $1-5$ miles & 24.3 & 16.1 \\
\hline $5-10$ miles & 9.7 & 20.4 \\
\hline $10-50$ miles & 24.3 & 22.6 \\
\hline $50-100$ & 5.8 & 6.5 \\
\hline Over 100 miles & 18.4 & 9.7 \\
\hline Over 1,000 miles & 0.0 & 7.5 \\
\hline All distances & 100 & 100
\end{tabular}

Yet about $24 \%$ of the respondents to both surveys were long-distance LATs, living over 50 miles apart, with 10\% (CNSS) and 18\% (ESP) over 100 miles apart. Indeed, seven of the LATs on the national survey reported that they lived over 1,000 miles apart, thus at airplane rather than automobile distance from one another.

Although it obviously depended on distance, the vast majority of LATs saw one another in person daily or weekly; at least $64 \%$ were together at least several times a week.

Table 3. Frequency of face-to-face contact of LATs in NY and US

\begin{tabular}{l|c|c}
\hline Frequency & \% of LATs: NY & \% of LATs: US \\
\hline $\begin{array}{l}\text { One of more times } \\
\text { a day }\end{array}$ & 25.2 & 23.7 \\
\hline $\begin{array}{l}\text { Several times a } \\
\text { week }\end{array}$ & 41.7 & 39.8 \\
\hline Once a week & 7.8 & 15.1 \\
\hline $\begin{array}{l}\text { Several times a } \\
\text { month }\end{array}$ & 10.7 & 3.2 \\
\hline $\begin{array}{l}\text { At least once a } \\
\text { month }\end{array}$ & 4.9 & 9.7 \\
\hline Less often & 9.7 & 8.5 \\
\hline All contacts & 100 & 100
\end{tabular}

And they had frequent contact by phone, text, or email when they were apart, $92 \%$ to $95 \%$ of them on a daily basis. 
Table 4. Frequency of non-face-to-face contact of LATs in NY and US

\begin{tabular}{l|c|c}
\hline Frequency & \% of LATs: NY & \% of LATs: US \\
\hline Several times a day & 78.6 & 81.7 \\
\hline Once a day & 12.6 & 12.9 \\
\hline $\begin{array}{l}\text { Several times a } \\
\text { week }\end{array}$ & 6.8 & 4.3 \\
\hline Once a week & 1.0 & 1.1 \\
\hline $\begin{array}{l}\text { Several times a } \\
\text { month }\end{array}$ & 1.0 & 0.0 \\
\hline Less often & 0.0 & 0.0 \\
\hline All frequencies & 100 & 100
\end{tabular}

Thus, while maintaining separate residences, these LATs saw their partners very often and kept in touch typically on a daily basis.

The gender ratio overall among respondents to both the New York and national surveys was virtually 50/50: $51 \%$ male and $49 \%$ female. Similarly, LATs among the New York respondents divided 50/50 into male and female. However, LATs in the CNSS were 55\% male and $45 \%$ female, which could be an artifact of random sampling.

The ratio of same-sex to different-sex-coupled respondents differed on the two polls, with same-sex LATs making up $4 \%$ of all LATs on the national poll and $11 \%$ in New York, which may reflect the more liberal and gay-friendly atmosphere of parts of New York State. On the national survey, the percentage of LATs in same-sex relationships in California alone, a state with a very high percentage of same-sex couples, ${ }^{94}$ was $14 \%$. One author who has studied LATs in California has suggested that living apart is a more discreet, and thus safer, lifestyle for gay males. ${ }^{95}$

The distribution of LATs among racial groups in the United States, as set forth in Table 5, yielded some results that were surprising in comparison with the percentages of those groups in the overall samples. Readers should note that totals for each column (not given in the table) exceed $100 \%$, because Hispanic, Black, and White are not mutually exclusive categories, and the survey asked about race in separate questions for each category. A considerable number of respondents

\footnotetext{
${ }^{94}$ More than $15 \%$ of all same sexcouples in the United States live in California. C Carpenter and GJ Gates, 'Gay and Lesbian Partnership: Evidence fromCalifornia', 45 Demography 573, 574 (2008).

${ }^{95}$ Strohmet al., above note 5, p 178.
} 
obviously replied that they were in more than one category, and each of those responses has been counted separately, resulting in totals exceeding 100.

Table 5. Distribution by race of LATs in NY and US, compared with all respondents

\begin{tabular}{lcccc}
\hline Race & $\begin{array}{c}\text { \% of } \\
\text { LATs: NY }\end{array}$ & $\begin{array}{c}\text { \% of all } \\
\text { respondents: NY }\end{array}$ & $\begin{array}{c}\text { \% of } \\
\text { LATs: US }\end{array}$ & $\begin{array}{c}\text { \% of all } \\
\text { respondents: US }\end{array}$ \\
\hline Hispanic & 19.35 & 13.1 & 19.35 & 9.2 \\
\hline White & 76.34 & 69.5 & 76.34 & 83.1 \\
\hline Black & 12.90 & 21.5 & 12.90 & 10.1 \\
\hline $\begin{array}{l}\text { Native } \\
\text { American }\end{array}$ & 6.45 & 2.4 & 6.45 & 6.4 \\
\hline Asian & 7.53 & 5.9 & 7.53 & 4.7 \\
\hline Other & 2.15 & 5.6 & 2.15 & 1.9 \\
\hline
\end{tabular}

The surprising results were the overall distribution of LATs among all racial groups and, in particular, the prominence of Hispanics among LATs both in New York State and nationally, where they lived apart at double the percentage they represented within the sample population as a whole. The reason for surprise at these findings was the assumption found in the literature described above in Part I that LATs were to be found primarily among the more economically well-off individuals in the population, whereas Hispanics and other persons of colour are among the most vulnerable groups in this respect. Some of the disparity disappears in comparison with official national census statistics on race from 2015, which report that Hispanic individuals made up $18 \%$ of the population as a whole - close to the $19 \%$ reported as LATs in our national survey. ${ }^{96}$ Another anomaly was the fact that Black women LATs outnumbered Black male LATs almost by two to one, a gender imbalance that may be the effect of the very high incarceration rates of Black males.

The majority of LAT respondents were employed: 68\% in New York State and 65\% nationally; $73 \%$ of those employed nationally had full-time work, and 68\% of those employed in New York. ${ }^{97}$ Retirees made up only $4 \%$ of LATs in New York State, but $10 \%$ nationally. Their

\footnotetext{
${ }^{96}$ US Census Bureau, QuickFacts, available at https://www.census.gov/quickfacts/table/PST045216/00, last accessed 10 Apr 102017.

${ }^{97}$ The remainder who were employed had various types of temporary, seasonal, or contract-based work.
} 
prominence nationally may indicate, as discussed above and in the developing literature, that LAT is an increasingly attractive living arrangement for older adults.

Table 6 shows the distribution of household incomes among LATs in New York State and nationally, compared to the household income distribution in the national sample and in statistics obtained from the Census Bureau. ${ }^{98}$

Table 6. Distribution of household income of LATs in NY and US, compared with all respondents and Census data

\begin{tabular}{|c|c|c|c|c|c|}
\hline Income & $\begin{array}{c}\% \text { of } \\
\text { LATs: } \\
\text { NY }\end{array}$ & $\begin{array}{c}\% \text { of all } \\
\text { Respondents: } \\
\text { NY }\end{array}$ & $\begin{array}{c}\% \text { of } \\
\text { LATs: } \\
\text { US }\end{array}$ & $\begin{array}{c}\% \text { of all } \\
\text { respondents: } \\
\text { US }\end{array}$ & $\begin{array}{c}\text { Census } \\
\text { Statis tics }^{99}\end{array}$ \\
\hline$<\$ 10,000$ & 9.09 & 3.60 & 4.40 & 2.40 & 6.9 \\
\hline \$10-\$19,999 & 5.05 & 5.40 & 8.79 & 5.10 & \\
\hline \$20-\$29,999 & 9.09 & 5.80 & 8.79 & 7.10 & \\
\hline \$30-\$39,999 & 9.09 & 7.80 & 8.79 & 5.30 & \\
\hline$\$ 40-\$ 49,999$ & 12.12 & 13.80 & 9.89 & 11.80 & \\
\hline$\$ 50-\$ 74,999$ & 20.20 & 23.40 & 29.67 & 29.60 & 17.8 \\
\hline \$75-\$99,999 & 16.16 & 12.90 & 12.09 & 12.10 & 12.2 \\
\hline $\begin{array}{l}\$ 100- \\
\$ 149,999\end{array}$ & 17.17 & 15.80 & 8.79 & 13.20 & 13.6 \\
\hline $\begin{array}{l}\$ 150,000 \\
\text { and over }\end{array}$ & 2.02 & 11.50 & 8.79 & 13.40 & 11.3 \\
\hline All income & 100 & 100 & 100 & 100 & 100 \\
\hline
\end{tabular}

A small majority of LATs lived in middle- to high-income households, $55 \%$ to $60 \%$ at or above a $\$ 50,000$ annual household income. For purposes of comparison, the national median household income in 2015, as calculated by the Census Bureau, was $\$ 55,775 .{ }^{100}$ What is remarkable is that LATs seem to distribute across the income spectrum, indicating that they are a broad-based, crossclass phenomenon.

\footnotetext{
${ }^{98}$ Four res pondents to the NY survey (103 total LATs) and six res pondents to the US survey (93 total LATs) did not ans wer this question, so this table reports res ponses from 99 and 87 LATs in each survey res pectively.

${ }^{99}$ The income dis tribution available from the Census Bureau is set forth only where it provides comparable statistics; the omitted groups, those with incomes from $\$ 10,000$ to $\$ 49,999$, made up $38 \%$ of the population on the census.

${ }^{100}$ U. S. Census Bureau, 'Income in the Past 12 Months (In 2015 Inflation-Adjusted Dollars),' 2015, available at American FactFinder (Census Bureau), https://factfinder.census.gov/bkmk/table/1.0/en/ACS/15_1YR/S1901/0100000US, last acces sed, 29 Jan 2017.
} 
Nationally and in New York, about 35\% of LATs had a college or higher degree, although this was lower than the percent in the national sample overall (46\%). As shown in Table 7, more than two thirds had at least some college education, with $30 \%$ or less having only a high school education or less. ${ }^{101}$

Table 7. Level of education attained by LATs in NY and US, compared with all respondents

\begin{tabular}{|c|c|c|c|c|}
\hline $\begin{array}{l}\text { Level of } \\
\text { education }\end{array}$ & $\begin{array}{c}\% \text { of } \\
\text { LATs: } \\
\text { NY }\end{array}$ & $\begin{array}{c}\% \text { of all } \\
\text { respondents: } \\
\text { NY }\end{array}$ & $\begin{array}{l}\% \text { of } \\
\text { LATs: } \\
\text { US }\end{array}$ & $\begin{array}{c}\% \text { of all } \\
\text { respondents: } \\
\text { US }\end{array}$ \\
\hline $\begin{array}{l}\text { Grades 1-8 } \\
\text { only }\end{array}$ & .97 & 1.40 & 1.08 & 0.80 \\
\hline $\begin{array}{l}\text { Grades 9- } \\
11\end{array}$ & 6.80 & 7.00 & 4.30 & 3.30 \\
\hline $\begin{array}{l}\text { High } \\
\text { school or } \\
\text { GED }\end{array}$ & 21.36 & 23.20 & 21.51 & 21.90 \\
\hline $\begin{array}{l}\text { Tech/trade/ } \\
\text { vocational } \\
\text { school }\end{array}$ & 3.88 & 2.50 & 2.15 & 2.00 \\
\hline $\begin{array}{l}\text { Some } \\
\text { college }\end{array}$ & 33.01 & 23.20 & 35.48 & 26.60 \\
\hline $\begin{array}{l}\text { College } \\
\text { graduate }\end{array}$ & 20.39 & 24.10 & 26.88 & 25.60 \\
\hline $\begin{array}{l}\text { Post- } \\
\text { graduate or } \\
\text { profession } \\
\text { al } \\
\end{array}$ & 13.59 & 18.70 & 8.60 & 19.90 \\
\hline $\begin{array}{l}\text { All } \\
\text { education } \\
\text { levels }\end{array}$ & 100 & 100 & 100 & 100 \\
\hline
\end{tabular}

LATs seem rather typical in educational achievement compared with the sample of all respondents. This does not confirm the positive correlation postulated in studies from other countries between level of education and living apart together. Yet overall, LATs are a fairly educated group.

Nearly a quarter of all LATs responding to the national survey lived in New York (9\% of LATs) and California (14\% of LATs), indicating perhaps that the lifestyle thrives in more liberal

${ }^{101}$ One respondent to the US survey (93 total LATs) did not answer this question. 
environments. All respondents to the ESP and CNSS were asked to characterise their social ideology. The LATs responded as in Table 8, as compared with the overall national sample. ${ }^{102}$

Table 8. Social ideology of LATs in NY and US

\begin{tabular}{lcccc}
\hline Social ideology & $\begin{array}{c}\text { \% of } \\
\text { LATs: } \\
\text { NY }\end{array}$ & $\begin{array}{c}\text { \% of all } \\
\text { respondents: } \\
\text { NY }\end{array}$ & $\begin{array}{c}\text { \% of } \\
\text { LATs: } \\
\text { US }\end{array}$ & $\begin{array}{c}\text { \% of all } \\
\text { respondent: } \\
\text { US }\end{array}$ \\
\hline Extremely liberal & 7.07 & 7.10 & 4.30 & 6.00 \\
\hline Liberal & 15.15 & 15.70 & 21.51 & 17.30 \\
\hline Slightly liberal & 11.11 & 9.70 & 7.53 & 6.40 \\
\hline $\begin{array}{l}\text { Moderate/Middle } \\
\text { of the road }\end{array}$ & 38.38 & 37.00 & 36.56 & 33.90 \\
\hline $\begin{array}{l}\text { Slightly } \\
\text { conservative }\end{array}$ & 12.12 & 8.90 & 8.60 & 11.50 \\
\hline Conservative & 8.08 & 14.50 & 13.98 & 16.80 \\
\hline $\begin{array}{l}\text { Extremely } \\
\text { conservative }\end{array}$ & 8.08 & 7.00 & 6.45 & 8.20 \\
\hline All ideologies & 100 & 100 & 100 & 100
\end{tabular}

Although the LATs were somewhat more liberal and somewhat less conservative than the national sample, the group basically divided into thirds across the spectrum, with most falling solidly in the middle of the road. Thus, it does not seem that LATs as a whole see themselves as radical in any way, even if they may be developing a radically new lifestyle. This finding is consistent with the conclusion reached in a study of LATs in Scotland, who typically had no name for their status and were not aware that they were setting a new trend, 'Yet,' its authors commented, 'at the same time they were accumulating a particular practical knowledge of being a couple that is likely to contribute to ultimately shifting meanings.' 103

Age Distribution and Reasons for Living Apart

The age distribution of respondents is shown in Table 9.

\footnotetext{
${ }^{102}$ On the NY survey (103 totalLATs), 12 res pondents answered "do not know" to this question and an additional four refused to answer, so this table reports findings for 87 NY LAT respondents; one respondent did not answer this question on the US survey (93 total LATs), so the total number res ponding to that was 92.

${ }^{103}$ Jamies on and Simpson, above note 22, p 84.
} 
Table 9. Age distribution of LATs in NY and US

\begin{tabular}{ccccc}
\hline Age & $\begin{array}{c}\text { \% of } \\
\text { LATs: } \\
\text { NY }\end{array}$ & $\begin{array}{c}\% \text { of all } \\
\text { respondents: } \\
\text { NY }\end{array}$ & $\begin{array}{c}\% \text { of } \\
\text { LATs: } \\
\text { US }\end{array}$ & $\begin{array}{c}\text { \% of all } \\
\text { respondents: } \\
\text { US }\end{array}$ \\
\hline $18-24$ & 23.30 & 11.00 & 29.03 & 10.50 \\
\hline $25-34$ & 21.36 & 15.50 & 26.88 & 12.80 \\
\hline $35-44$ & 15.53 & 16.88 & 11.83 & 12.70 \\
\hline $45-54$ & 23.30 & 21.25 & 16.13 & 19.40 \\
\hline $55-64$ & 10.68 & 17.38 & 7.53 & 21.60 \\
\hline $\begin{array}{c}65 \text { and } \\
\text { older }\end{array}$ & 5.83 & 18.00 & 8.60 & 23.00 \\
\hline Total & 100 & 100 & 100 & 100
\end{tabular}

Classifying the group aged 18 to 24 as 'young', less than a quarter of the total LATs sampled in New York State and less than $30 \%$ nationally fall into that 'young' bracket, lower than estimates from the UK and Europe. These are the LATs who might be expected still to be students and dependent on their parents. If age 55 and up is taken as 'older,' then only about $16-17 \%$ of the LATs fell into that group both in New York and nationally. There were fewer (6\% to 9\%) than I expected of retirement age. In short, the vast majority of LAT respondents in the US surveys fell into the midlife group.

When asked for the primary reason they lived apart, the LATs gave a variety of responses to the options they were given, as set forth in Table 10. 
Table 10. Primary reason for living apart given by LATs

\begin{tabular}{lcc}
\hline Primary Reason & \% of LATs: NY & \% of LATs: US \\
\hline Constraints & & 22.6 \\
\hline Too early & 18.8 & 14.0 \\
\hline Job-related reasons & 14.9 & 7.5 \\
\hline $\begin{array}{l}\text { Study-related } \\
\text { reasons }\end{array}$ & 11.9 & 4.2 \\
\hline $\begin{array}{l}\text { Because of my or } \\
\text { my partner's } \\
\text { children }\end{array}$ & 6.9 & 6.5 \\
\hline $\begin{array}{l}\text { Because of other } \\
\text { responsibilities }\end{array}$ & 10.9 & \\
\hline $\begin{array}{l}\text { Preferences } \\
\text { Want to keep own } \\
\text { home for other } \\
\text { reasons }\end{array}$ & 9.9 & 7.5 \\
\hline $\begin{array}{l}\text { Live apart by } \\
\text { preference }\end{array}$ & 26.7 & 15.1 \\
\hline 'Other reasons & Not offered in survey & 22.6 \\
\hline $\begin{array}{l}\text { All reasons } \\
\text { 100 }\end{array}$ & 100
\end{tabular}

When categorised into reasons reflecting constraints (the first five reasons given) and those that were voluntary, $23 \%$ of the national sample (who also had the 'other reasons' option, not available to NY respondents) but almost $37 \%$ of the group from New York indicated that they were LATs by preference. This result is consistent with the finding reported above that LAT relationships in New York were longer in duration, which is characteristic of older LAT couples who have freely chosen to live apart.

\footnotetext{
${ }^{104}$ The option 'other reas ons' was notgiven on the New York State survey. However, two LAT res pondents answered that they did not know.
} 
The reasons given varied by age group, however. Figure 1 shows the distribution of reasons given on the national survey, correlated with the age group of the respondent.

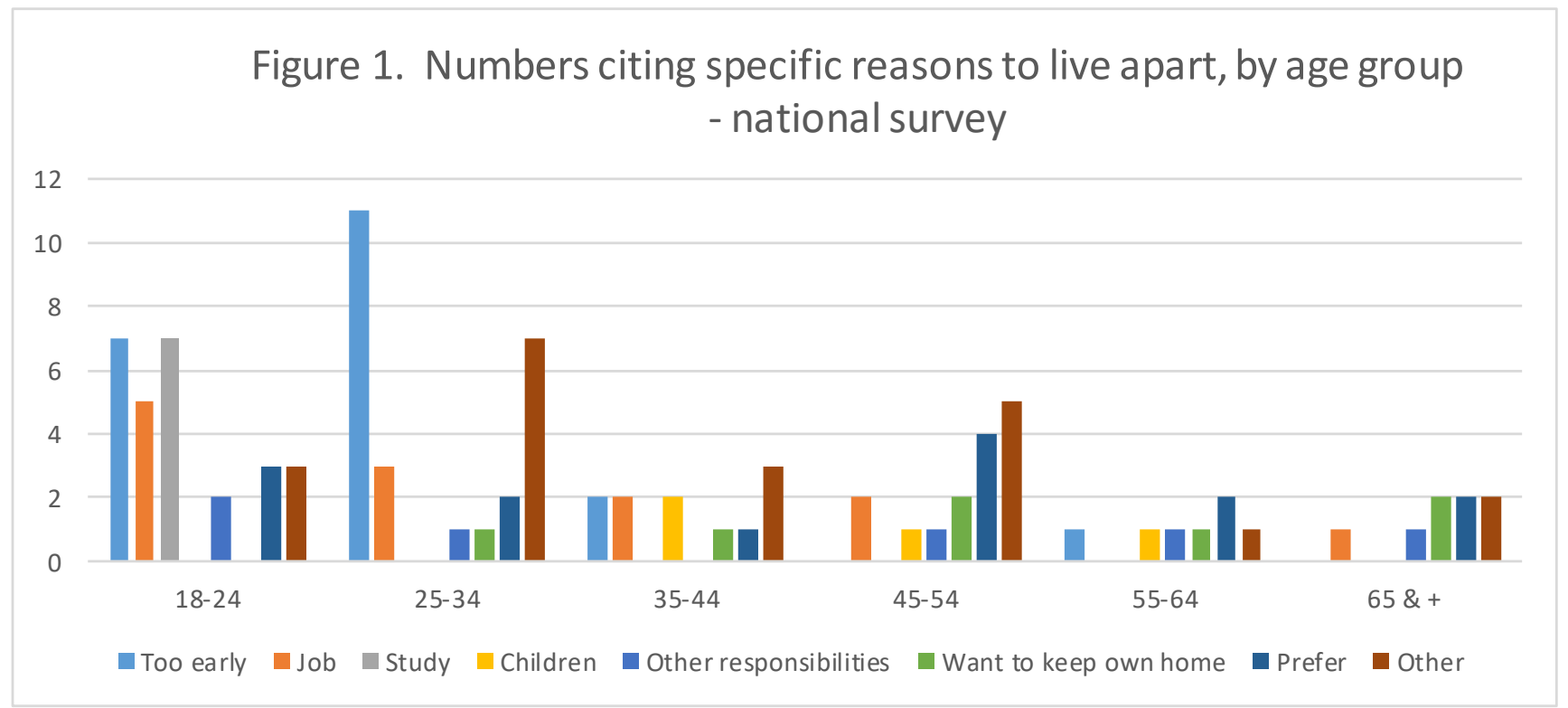

As one might expect, those who reported that it was too early to live together clustered in the age group from 18 to 34 , and those citing their studies fell exclusively within the category from 18 to 24. Those who were particularly influenced by the desire to stay in their own homes were older, the majority aged 45 and above. Motivation relating to children was cited as a primary reason by only four respondents, all of them over 35; this response could relate either to the presence of children in one of the partners' homes or a sensitivity on the part of older respondents to leaving the home where their children had been raised and still regarded as home. 'Other responsibilities', with elder care suggested in the question, was cited by more of the LATs than was 'children'.

What is remarkable about the distribution of responses is that 'preference' unrelated to any of the other options was cited by so many respondents (14) and that they were arrayed across the age groups, with a substantial proportion among the young and midlife groups; a minority were 55 and up, the group in which I expected to find most LATs by preference. The biggest lesson, however, is that the largest total group - 21 - arrayed across all ages, answered 'other,' indicating that the categories I took from the British Social Attitudes Survey need to be expanded. My qualitative interviews suggest that matters of personal style and, in particular, messiness or clutter versus a preference for a tidy and/or minimalist décor play a large role in these decisions. 


\section{Economics and Caretaking}

When asked if they shared costs for joint activities, $85 \%$ of the LATs sampled in New York and $77 \%$ nationally said that they did. Because the answer to this question was ambiguous (not sharing could mean one partner always paid), questions about the method of cost-sharing were added to the CNSS; responses are displayed on Table 11 for the 72 out of 93 national survey respondents who answered this question, whereas all answered the basic question on whether costs shared.

Table 11. Method of sharing joint costs employed by LATs in US

\begin{tabular}{l|c|c}
\hline Method & \# of respondents & \% of LATs \\
\hline Strictly 50/50 & 12 & 16.7 \\
\hline $\begin{array}{l}\text { According to ability } \\
\text { to pay }\end{array}$ & 13 & 18.1 \\
\hline $\begin{array}{l}\text { Alternating } \\
\text { payment }\end{array}$ & 39 & 54.2 \\
\hline $\begin{array}{l}\text { Each contributed to } \\
\text { a common pot }\end{array}$ & 4 & 5.5 \\
\hline Other & 4 & 5.5 \\
\hline All methods & 72 & 100
\end{tabular}

The four respondents who chose 'other', when asked to specify, indicated that one of the two always paid; the sole payor in each instance was a male. In short, only a very small proportion relied on methods typical of many married couples, especially those with children, ${ }^{105}$ such as contributions to a common pot or payment by the only wage earner. The vast majority of respondents said either that they alternated paying for items (54\%) or kept strict 50/50 accounts (17\%). Although some adjusted this for ability to pay, the underlying assumption of each partner's economic independence is inescapable. This appearance of economic independence is reinforced by the fact that the overwhelming majority $-89 \%$ - held no property of any kind in common. Consistent with this lack of economic interdependence, only 19\% of the LATs responding to the national survey had made any provision for their partner in case of their death; the largest single

${ }^{105}$ See C Vogler et al, 'Managing Money in New HeterosexualForms of Intimate Relationships', 37 J. SocioEconomics 552, 567 (Table 11) (2008) (married respondents and cohabiting parents use a joint pooling system); KR Heimdal \& SK Hous eknecht, 'Cohabiting and Married Couples' Income Organization: Approaches in Sweden and the United States', 65 J. Marriage \& Fam. 525, 533 (2003) (a majority of both married and cohabiting couples in the US and Sweden maintain joint finances). 
age group having done so was those between 45 and 55. Yet the vast majority of LATs seemed certain that their partner would help them financially if they were in difficulty: $80 \%$ said that their partners would be likely to help with a gift or loan, and only $20 \%$ said that they would not help at all.

The next set of questions sought to uncover various levels of commitment and caretaking, both physical and emotional, between the partners. When asked 'If you had an illness and had to stay in bed, who would be most likely to care for you?', 24\% the LAT respondents nationally (27\% in New York) said their partner would; $54 \%$ (50\% in New York) said a family member would; and $10 \%$ ( $8 \%$ in New York) said 'someone who lives with me'. The remaining responses were scattered among 'a friend' and 'other.' Although the percent who would rely on family was higher among the younger age groups (63\% among the 18-24 group), it constituted the majority across all age groups. In this respect, the Americans were like their British counterparts (and unlike the Swedes) in expecting more in the way of physical caretaking from members of their biological families than from their LAT partners. In the case of LATs who were elderly or lived quite a distance apart, they may also have perceived their partners as unable to offer physical care if they were disabled.

Yet when asked whom they would talk to if they were upset, almost half of the national sample prioritised their partner.

Table 12. Person LAT is most likely to talk to when upset

\begin{tabular}{lcc}
\hline Person & \% of LAT: NY & \% of LATs: US \\
\hline Partner & 36.9 & 49.5 \\
\hline Family member & 35.9 & 19.4 \\
\hline $\begin{array}{l}\text { Someone who lives } \\
\text { with you }\end{array}$ & 3.9 & 5.4 \\
\hline A friend & 16.5 & 24.7 \\
\hline Other & 3.9 & 1.0 \\
\hline Nobody & 1.9 & 0.0 \\
\hline Don't know & 1.0 & 0.0 \\
\hline All persons & 100 & 100
\end{tabular}

In short, these LATs expected emotional support from their partners even when they did not expect physical care. 


\section{Interview Findings}

The 18 interviews that I conducted with LATs (mostly couple-interviews) differed substantially from those surveyed, most notably by age and duration of relationship, probably because they were recruited by an older academic. Their ages ranged from 56 to 83, and the average duration of their relationships was 21.5 years (ranging from 1.5 to 39 years), so these interviews capture the experience of a distinctive subset of the total LAT population. They all lived in the same town as one another, with the exception of one couple who were 2,000 miles apart. One couple had lived together in the past, then moved apart and were happier that way. Eight of the women were divorced, and one widowed. They were all economically self-sufficient, and most split joint costs, either by alternating or 50/50, but described themselves as being very relaxed about it.

Several results contrast with the findings from the surveys described above as well as in the secondary literature. In three of the four couples in which there was an income disparity between partners, the woman was better off than the man; as a result, in three of the four couples in which one partner paid all the costs of joint activities, that partner was the woman. Moreover, some co-owned property together - a vacation home, a camper van, a workshop - and short-term financial assistance between partners was relatively common. Any jointly owned assets were acquired during the LAT relationship and did not represent a large part of either partner's assets. Yet fully 11 of the 18 had made wills providing for their partners, and two more intended to do so; the four who did not leave money to their partners had children and grandchildren and a partner well able to take care of him- or herself. In short, there were more indices of economic interdependence than expected, although each LAT remained economically self-sufficient.

Moreover, physical caretaking had occurred in seven couples, perhaps showing that the predictions of LATs surveyed are not as accurate as what actually happens when the need occurs. In four of those couples, each partner had rendered major caregiving services to the other, such as moving in to provide several weeks of post-operative care. In three couples, contrary to the stereotypical expectation, the male partner was the caretaker. All the interviewees relied first on their partners for emotional support, would talk to them about problems about which they were upset, and went to them for physical comfort and solace. In short, they were providing for each other many of the functions we associate with family. This may reflect their age and length of 
commitment, while the survey data included respondents as young as 18 years old and others who could still look to their families of origin for physical caretaking.

\section{How Should the Law Treat LATs?}

When I began to consider LAT relationships, I was struck by the differences from cohabitation, in particular, by the lack of financial interdependence exhibited by cohabitants. LATs by definition each have their own homes and the protection that entails against extreme vulnerability upon separation or death. LATs also appear to be a fairly well-educated group, so perhaps we can simply rely on them to enter into other legal arrangements, such as drafting wills and executing contracts to address their own needs. After the analysis described in this article, however, and in response to needs perceived in my qualitative interviews, I have concluded that a number of legal remedies should be provided for LATs. The bases for this conclusion are both my developing insight into the functions of adult affiliations in the modern world and various suggestions made by the LATs interviewed.

The best way to approach the question whether LATs should be given more attention by the legal system is to begin with an inquiry into the goals of our family law system. Depending on one's perspective, there are a variety of public policy goals to aim for. One is to use the law to encourage marriage and/or cohabitation, whether for moral or pragmatic reasons. If this is the goal, then law and policy should seek to address constraints on living together, including both legal disincentives to doing so and other obstacles, such as a shortage of affordable housing. This is also the way to go if one's aims specifically include the privatization of welfare, as in countries where marriage law seems to have that function. US law appears to follow this approach, but only with respect to encouraging marriage, for it is generally quite punitive in its treatment of cohabitation and sees marriage as the ideal. ${ }^{106}$ However, this is also an approach taken by some US scholars with respect to the legal treatment of cohabitation. ${ }^{107}$

Alternatively, one may prioritise individual autonomy and choice, seeking to allow individuals the freedom to choose whatever living arrangements they desire for themselves. In

\footnotetext{
${ }^{106}$ CG Bowman, Unmarried Couples, Law, and Public Policy (Oxford University Press, 2010), at p 2.

${ }^{107}$ ES Scott and REScott, 'FromContract to Status: Collaboration and the Evolution of Novel Family Relationships', 115 Columbia Law Review 293, 314 (2015) (arguing that the law should recognis ean adult affiliation when it relieves the state of its obligation to care for dependency).
} 
this case, law and policy should seek to be neutral in their treatment of marriage, cohabitation, and other forms of adult affiliation; Swedish law provides an example of this approach. ${ }^{108}$ If individuals receive health care, pensions, and adequate living conditions as individuals rather than based on their family status, they may choose to marry, cohabit, or live apart without constraint. Thus, the ability of individuals to rely upon the state if they are unable to care for themselves appears to be a necessary prerequisite of such neutrality and resulting freedom of choice.

Finally, the goal of a family law system may be simply to protect vulnerable parties at the end of their relationships, regardless of the relationship form they have chosen. If so, the law should address situations in which participation in a committed relationship may leave one of the parties vulnerable at its end, to compensate them for relationship-generated disadvantages. These parties are protected under a welfare system such as that in Sweden, but this goal can also be accomplished by privatizing welfare through extending many of the rights and obligations of marriage to persons in marriage-like relationships in countries without social welfare protections. This has been the approach I have advocated in my own work on cohabitation, directed at the US setting as it currently exists, a system without the social and economic supports available in a social welfare state such as Sweden. 109

One particular article influenced my thinking about what protections should be extended to LATs, Jessica Feinberg's 2014 piece addressing the general question of what legal recognition should be given to adult affiliations such as domestic partnerships and civil unions in the era of same-sex marriage: would they - should they - survive? ${ }^{110}$ Feinberg argued that we should create a comprehensive system of adult relationship recognition that does not depend on marriage, because a system focused on marriage leaves many couples without necessary protections. ${ }^{111}$ She recommended establishing partnership recognition schemes to address the needs of people living

\footnotetext{
${ }^{108}$ For a discussion of the Swedish policy decision in favor of neutrality, see Sörgjerd, above note 1, at 139-44.

109 Bowman, above note 106, pp 223-230. See also WNEskridge, Jr., 'Family Law Pluralism: The Guided-Choice Regime of Menus, Default Rules, and Override Rules', 100 Georgetown Law Journal 1881, 1890 (2013) (including the protection of vulnerable persons among the goals of family law in the context of an argument for legal protection of cohabitants).

${ }^{110}$ JR Feinberg, 'The Survival of Nonmarital Relationship Statuses in the Same-Sex Marriage Era: A Proposal', 87 Temple Law Review 45 (2014).

${ }^{111}$ Ibid, p 45.
} 
in the divers forms of family that exist today. ${ }^{112}$ To accomplish this, she proposed that states create a non-marital status with a default regime of separate property and a package of rights that included certain minimum core protections, such as family and medical leave, hospital visitation rights identical to those of a spouse, preference for designation as healthcare proxy, power of attorney, and guardian, presumption of parentage of any child born during the union, rights of step-parents and standing to seek visitation of the other partner's children, and domestic violence protections. ${ }^{113}$ This would be an opt-in system requiring registration. ${ }^{114}$ States might also wish to provide rights with respect to inheritance, taxes, testimonial privileges, support and liability for debt, and claims in tort and contract. ${ }^{115}$ The rights included should be those related to the ability of the partners to care for each other and not those predicated on economic interdependence. ${ }^{116}$

I disagree with Feinberg about the desirability of creating an opt-in system requiring registration, because most people fail to ensure that they are protected when it requires them to take affirmative action. ${ }^{117}$ I also believe that courts will be able to discern which couples fall into this category, as they have learned to do in the case of cohabitants and are learning to do in cases that require them to distinguish between LATs and cohabitants. ${ }^{118}$ Nonetheless, Feinberg's list suggests a number of legal changes that would protect LATs and, in so doing, the society at large, as it focuses on the state-created rights and benefits necessary to be a caring partner, even if living apart. After reading her article, I decided to ask my (older) interviewees an open-ended question about what legal changes they needed. ${ }^{119}$ Their list of concerns was almost identical to Feinberg's.

\footnotetext{
${ }^{112}$ Ibid, p 67.

${ }^{113}$ Ibid, pp 81-83.

${ }^{114}$ Ibid, p 82.

${ }^{115}$ Ibid, p 83.

${ }^{116}$ Ibid, p 85.
}

117 JK Robbennolt and MK Johnson, 'Legal Planning for Unmarried Committed Partners: Empirical Les sons for a Preventive and Therapeutic Approach ', 41 Arizona Law Review 417, 435-436, 439, 441 (1999) (describing Minnesota study that found that only 21 percent of committed unmarried couples had written agreements).

${ }^{118}$ See, eg, Dunphyv Gregor, 642 A2d 372 (NJ 1994) (articulating standard to distinguish cohabitants in case for negligent infliction of emotional dis tress); In re Marriage of Miller, 40 NE3d 206 (2d Dist 2015) (developing standard to distinguish LAT fromcohabitant in caseinvolving termination of alimony by ex-spouse).

${ }^{119}$ The only other article reporting on interviewees' attitudes toward their legal treatment is S Duncan et al., 'Legal Rights for People Who "Live Apart Together"?, 34 Journal of Social Welfare and Family Law 443, 451 (2012). The 
One LAT was concerned that her partner might not be admitted to see her in a hospital intensive care unit, where visitors are limited to close family members. Another said she had been unable to care for her partner post-surgery because he did not fall within the category of persons for whom she was allowed to take family or compassionate leave from her job. Yet another brought up the fact that her partner had a good health insurance policy through her employer but could not cover her partner under the family policy. Another LAT mentioned that her partner was the beneficiary of her largest asset, her accumulated pension benefits, but, unlike a spouse, would receive it as a lump sum and be required to pay income tax on it, whereas it would be tax-free to a spouse and could be annuitised. One said she thought a registration system should be provided for those who wanted to register their partnerships and receive whatever package of benefits that might convey. Finally, one LAT, who was a lawyer, said that implied contracts between LAT partners should be recognised, just as they are for cohabitants. ${ }^{120}$ This was the broadest proposal and would create legal actions for support or property distribution upon dissolution of the relationship, based on implying a contract either from the conduct of the parties or on equitable principles.

Based on these suggestions and Feinberg's analysis, I propose that the following legal rights, at a bare minimum, should be conferred upon committed couples who live apart:

- an extension of hospital visitation that is limited to family members,

- eligibility for family and medical leave to care for a LAT partner,

- reform of pension regulations so that passage of pension benefits to a committed partner, whether cohabiting or not, be a non-taxable event, and

- the ability to add one's partner to one's health insurance plan.

Second, a system of partnership registration should be provided for those LATs who desire it, a system with default rules such as those Feinberg suggests but the ability to include more specific terms. Another valuable reform, addressing problems that arise in many US states, would be revision of the alimony law in states that do not currently recognise its rationale as the economic need of the recipient. The goal would be to make it clear that termination of support to an ex-

authors inquired if the 50 res pondents thought LATs should have rights similar to married couples as to inheritance and child support. The answers divided almos tequally in to three groups - those who thought they should, those who thought they should not, and those that thought it depended on the circumstances.

${ }^{120}$ Most US states, following Marvin v Marvin, 18 Cal. 3d 660, 674, 684-685 (1976), recognise contracts between cohabitants, either expres s or implied. 
spouse should rest solely on changed circumstances affecting that person's economic need and not upon his or her intimate relationships - that is, just being a LAT is not grounds to terminate alimony. (Statutes in many US states provide that alimony will terminate upon cohabitation, and these provisions have swept LATs into their net.) ${ }^{121}$

Finally - and by way of much longer-run wish-fulfillment - welfare benefits, health care insurance, and pensions in the United States should run to individuals and not be based on family or marital status, thus making individuals free to choose the living arrangement that is right for them without fearing the economic consequences of doing so. These legal changes would provide some minimum legal protections to persons who choose to live apart, thus allowing them to choose without constraint among the variety of living arrangements now available. These include living apart together, a lifestyle that appears to suit the needs of a growing minority of the population.

\section{Conclusion}

This article has described the living arrangement of a little-discussed group, committed unmarried couples who maintain separate residences. LATs comprise substantial, and apparently increasing, numbers of people, although only a small minority of the population overall. They consist of a diverse group, with their reasons for living apart differing, in particular, according to the age cohort, or life stage, of the partners. ${ }^{122}$ LATs provide many valuable functions for one another, many of them, such as caregiving in illness, associated with what families do.

The empirical work I have initiated, although limited by its sample size, suggests some facts about LATs in the US that diverge from assumptions in the previous literature, particularly in the subset of older LATs whom I interviewed. Unlike generalizations contained in studies from other countries, for example, LATs in the US appear to resemble the general population in income and education and to present a genuinely cross-class and cross-cultural phenomenon. The prominence among LATs of some groups, such as Hispanics and Blacks, was unexpected and deserves further study. Substantial numbers of those who live apart do so out of preference for this form of intimate relationship and not out of external necessity. Older LATs with long-standing

\footnotetext{
${ }^{121}$ See, e.g., Rehmv Rehm, 409 SE2d 723 (NC App 1991); Paulv Paul, 60 A2d 1080 (Del 2012); In re Marriage of Herring, 634 NE2d 1168 (Ill App 1994); In re Marriage of Susan, 856 NE2d 1167 (Ill App 2006).

${ }^{122}$ Age cohort refers to a group born in a particular year or period, and thus sharing similar his torical and cultural experiences, whereas life stage refers to periods within the life span of each individual.
} 
relationships whom I interviewed also displayed a good deal more economic interrelationship than expected, with some co-owning property, inter-party loans being common, and the majority designating their partner as the primary beneficiary of their estates.

This article continues my exploration about what conclusions can be derived from social scientific data for deciding upon the appropriate legal treatment of a particular group. ${ }^{123}$ After reviewing the information currently available about LATs, I have recommended certain types of law reform appropriate to what we know about them. Those reforms are limited, by and large, to ones that will make it easier for these couples to care for one another in a practical sense, such as hospital visitation and family leave. Broader reforms, such as assimilating LATs to the status of co-residential couples, are not desirable, largely because LATs, unlike cohabitants, are economically self-sufficient and therefore not as vulnerable at the end of their relationships. Yet the law should also not place obstacles or disincentives in the path of this group. In the face of a world in which increased mobility, economic insecurity, and gender equality have made intimate connection more problematic yet perhaps more necessary than ever, many LAT couples have developed a living arrangement that combines independence with intimacy, one which works for them.

${ }^{123}$ CG Bowman, 'Social Science and Legal Policy: The Case of Heterosexual Cohabitation', 9 Journal of Law and Family Studies 1 (2007). 